\title{
Effective silencing of EGFR with RNAi demonstrates non-EGFR dependent proliferation of glioma cells
}

\author{
ARABEL VOLLMANN ${ }^{1,4}$, HANS-PETER VORNLOCHER ${ }^{3}$, THOMAS STEMPFL ${ }^{4}$, \\ GERO BROCKHOFF $^{1}$, RAINER APFEL ${ }^{5}$ and ULRICH BOGDAHN ${ }^{2}$ \\ Departments of ${ }^{1}$ Pathology, ${ }^{2}$ Neurology, University of Regensburg, Regensburg; ${ }^{3}$ Alnylam Europe AG, \\ Kulmbach; ${ }^{4}$ Center of Excellence for Fluorescent Bioanalysis, Regensburg; \\ ${ }^{5}$ Teva Pharmaceuticals Germany GmbH, Kirchzarten, Germany
}

Received August 31, 2005; Accepted October 21, 2005

\begin{abstract}
The epidermal growth factor receptor (EGFR, ErbB1) is frequently dysregulated in a variety of solid human tumors, including malignant glioma. EGFR expression has been associated with disease progression, resistance to standard therapies and poor survival. The application of small interfering RNAs (siRNAs) has become an effective and highly specific tool to modulate gene expression, and a wide range of oncogenes have been silenced successfully. Here we show the siRNA-mediated down-regulation of EGFR in two established glioma cell lines with different EGFR expression levels (U373 MG, LN18). The expression of EGFR mRNA and protein was down-regulated by $70-90 \%$. However, siRNA treatment had no inhibitory effect on cell proliferation, migration and activation status of EGFR-coupled signaling cascades. In accordance with these results, gene expression analysis with microarrays revealed only small, albeit specific changes in expression patterns. In conclusion, these data indicate that the specific down-regulation of EGFR might not be sufficient for a single agent therapeutic approach in malignant glioma.
\end{abstract}

\section{Introduction}

Malignant glioma represent the most common primary brain tumors in the adult. Their anatomical localization, the infiltration of the surrounding normal brain parenchyma

Correspondence to: Dr Arabel Vollmann, Department of Pathology, University of Regensburg, Franz-Josef-Strauss-Allee 11, D-93053 Regensburg, Germany

E-mail: arabel.vollmann@exfor.uni-regensburg.de

Abbreviations: EGFR, epidermal growth factor receptor; siRNA, small interfering RNA; GBM, glioblastoma multiforme

Key words: AG1478, epidermal growth factor receptor, gene expression analysis, glioma, siRNA and the suppression of a tumor-directed immune response contribute to their highly aggressive phenotype. Despite extensive efforts to improve surgery, radiotherapy and chemotherapy, the median survival for patients with glioblastoma multiforme (GBM) averages only 14 months (1). One of the most frequently altered genes in glioblastoma is the epidermal growth factor receptor (EGFR, ErbB1, HER-1). EGFR gene amplification occurs in 40-50\% of GBM, and tumors without amplification might also display an overexpression of this receptor (2-4). A common mutation (EGFRvIII), occurring in about half of the glioma with receptor amplification, confers enhanced tumorigenicity by rendering the receptor constitutively active (5). EGFR represents the prototype of class I receptor tyrosine kinases (RTKs). Besides EGFR, the ErbB family of receptors comprises three more members, ErbB2 (HER-2/NEU), ErbB3 (HER-3) and ErbB4 (HER-4). Receptor activation takes place after binding of specific ligands, e.g., epidermal growth factor (EGF), transforming growth factor $\alpha$ (TGF $\alpha)$, Amphiregulin, heparin-binding EGF (6). Ligand binding induces receptor homo- or heterodimerization and activation of the tyrosine kinase domain, which in turn phosphorylates both the receptor itself and downstream effector molecules. This results in signaling through multiple pathways, including the activation of extracellular regulated kinases $1 / 2$ (ERK1/2), protein kinase B (PKB) and members of the signal transducer and activator of transcription (STAT) family. Ultimately, cells respond with enhanced proliferation, migration and transcriptional activity, as well as decreased apoptosis (7-9). Several new strategies have been developed to target EGFR, including monoclonal antibodies (mAbs) (10), small molecule tyrosine kinase inhibitors (TKIs) (11), ribozymes (12) and antisense oligonucleotides (AS-ODNs) (13). Whereas $\mathrm{mAbs}$ and TKIs function by blocking EGFR activity, ribozymes and AS-ODNs inhibit its protein biosynthesis. An alternative approach to the latter methods is the use of small interfering RNAs (siRNAs), which show superior specificity and an up to 1000-fold higher efficiency in down-regulating target gene expression compared to AS-ODNs (14). Since the initial report of siRNA-mediated gene silencing in mammalian cells (15), siRNA technology has been established as a powerful tool to regulate gene expression or determine gene function. The therapeutic potential of this new class of 
molecules is highlighted by several in vitro studies showing marked down-regulation of a variety of oncogenes and in vivo by initial studies demonstrating successful application of siRNAs at least in some organs $(16,17)$.

The aim of this study was to examine the effect of siRNAmediated 'knockdown' of EGFR on established glioma cell lines. The specific down-regulation of protein and mRNA expression was shown, and the effect on cellular proliferation, anchorage-independent growth, migration and activation status of EGFR-coupled signaling cascades (ERK1/2, PKB) was examined. In addition, microarray analyses were performed to investigate the influence of EGFR down-regulation on global gene expression.

\section{Materials and methods}

Materials. Tyrphostin AG1478 [4(3-chloranilino)-6,7dimethoxyquinazoline] was purchased from Calbiochem (Bad Soden, Germany). Epidermal growth factor (EGF) and the anti-EGFR antibody for immunoblotting $(1 \mu \mathrm{g} / \mathrm{ml})$ were purchased from R\&D Systems (Minneapolis, MN, USA). Biotinylated anti-EGFR for flow cytometry (1:50) was purchased from Cymbus Biotechnology (Hants, UK). AntiB-actin antibody (1:5000) was obtained from Sigma (Steinheim, Germany). All other primary antibodies (1:1000) were purchased from Cell Signaling Technology (Frankfurt, Germany). Secondary antibodies for immunoblotting (1:5000) were purchased from Chemicon (Hofheim, Germany). Streptavidin-Cyan5 conjugate for flow cytometry (1:50) was from Jackson Immuno Research (West Grove, USA).

Cells and cell culture. U373 MG cells were obtained from the brain tumor bank of the Department of Neurology, University of Regensburg. LN18 cells were purchased from the American Type Culture Collection (ATCC No. CRL-2610). The cells were maintained in Dulbecco's minimal essential medium (DMEM), supplemented with $10 \%$ fetal calf serum (FCS), $5 \%$ non-essential amino acids and 5\% vitamin solution (all from Biochrom AG, Berlin, Germany) without antibiotics in a humidified atmosphere of $5 \% \mathrm{CO}_{2}$ at $37^{\circ} \mathrm{C}$. For ligand stimulation, cells were serum-starved for $24 \mathrm{~h}$ before addition of $100 \mathrm{ng} / \mathrm{ml} \mathrm{EGF}$.

siRNA transfection and inhibitor treatment. siRNAs were designed and synthesized by Alnylam Europe AG (Kulmbach, Germany) as duplexes of 21 nucleotides plus an asymmetrical overhang of two uridines at the 3'-end of the antisense strand. The sequence of the EGFR-specific siRNA (EGR10) corresponds to GenBank accession number NM_005228, positions 2456-2478. The control siRNA (EGR12) was identical in sequence to EGR10, but contained four mismatch point mutations at positions 4, 8, 12 and 16 of the sense strand. Transient transfections with siRNAs were performed using oligofectamine and serum-reduced optimem (both Invitrogen, Karlsruhe, Germany) according to the manufacturer's instructions and the guidelines published by Harborth et al (18). Unless indicated otherwise, a final siRNA concentration of $10 \mathrm{nM}$ was used. To obtain maximum transfection efficiency, cells were seeded $24 \mathrm{~h}$ prior to transfection such that $20-30 \%$ confluency was reached on the next day. Six hours post-transfection, the medium was replaced with standard culture medium. For inhibitor treatment, AG1478 was administered in parallel to siRNA transfections, i.e., concomitantly with the replacement of transfection medium.

Immunoblotting and flow cytometry. For immunoblots, cells were washed with ice-cold PBS followed by the addition of lysis buffer [1\% SDS, $50 \mathrm{mM}$ Tris-Cl pH 7.4, $5 \mathrm{mM}$ EDTA, $10 \%$ protease inhibitor cocktail solution (Sigma)]. The protein concentration was determined by BC Assay (Uptima, Montlucon Cedex, France). Equal amounts of protein were separated on $8 \%$ SDS gels and transferred to nitrocellulose (NC) membranes. NC membranes were blocked for $1 \mathrm{~h}$ in 5\% non-fat dry milk in phosphate-buffered saline (PBS) with $0.1 \%$ Tween and incubated overnight with primary antibodies at $4^{\circ} \mathrm{C}$. HRP-conjugated secondary antibodies were used for labeling ( $1 \mathrm{~h}$ at room temperature). Proteins were visualized by standard chemiluminescence methods.

For flow cytometry, cells were trypsinized and washed three times with PBS. Prior to the experiments it was shown that trypsinization did not affect EGFR surface expression as compared to non-enzymatic cell detachment by cell scrapers. Cells were then incubated on ice with biotinylated primary antibody for $1 \mathrm{~h}$, washed with PBS and incubated 45 min with Cyan-5-coupled streptavidin on ice. After washing with PBS, cells were resuspended in PBS and antigen detection was performed using the FACS Calibur System with CellQuest Software (BD Biosciences, San Jose, CA, USA).

Real-time PCR analysis. For quantification of specific mRNA transcripts, cell pellets were lysed and total RNA was extracted (Nucleospin RNAII, Macherey-Nagel, Düren, Germany). Reverse transcription was performed with SuperScript FirstStrand Synthesis System (Invitrogen) with amounts of total RNA ranging from $800 \mathrm{pg}$ to $2000 \mathrm{ng}$ per reaction and random hexamer primers $(25 \mu \mathrm{M})$. Amplification was performed using the 5'-nuclease method with pre-designed gene expression assays (TaqMan) on an ABI PRISM 7000 Sequence Detection System (Applied Biosystems, Foster City, USA) according to the manufacturer's instructions.

Proliferation assay. Cell number was determined using a crystal-violet staining assay (19). Briefly, cells grown in 96well culture dishes were fixed with $1.25 \%$ glutardialdehyde for $20 \mathrm{~min}$, washed with PBS and stained with $0.02 \%$ crystal violet solution ( $\mathrm{N}$-hexamethylpararosanilin $\mathrm{x} \mathrm{HCl}$ in $\mathrm{H}_{2} \mathrm{O}$ ) for $30 \mathrm{~min}$. The staining solution was removed by repeated washing of dishes with deionized $\mathrm{H}_{2} \mathrm{O}$. Nucleoprotein-bound crystal violet was solubilized by adding $70 \%$ ethanol and vigorous shaking for $2 \mathrm{~h}$. Staining intensity was measured with a microplate reader (Emax precision microplate reader, Molecular Devices, Munich, Germany) at an emission wavelength of $578 \mathrm{~nm}$.

Colony formation assay. Six-well plates were coated with DMEM containing 1\% FCS and 1\% low melting agar (Difco, Heidelberg, Germany). The next day, $10^{4}$ cells were resuspended in $2 \mathrm{ml}$ of DMEM with $1 \%$ FCS and $0.5 \%$ low melting agar, seeded in the prepared wells and overlaid with DMEM (1\% FCS). The medium was changed weekly. After 
Table I. Scoring system for evaluating transcripts as significantly regulated.

\begin{tabular}{lc}
\hline Parameters & Score \\
\hline Paired t-test MAS $5.0<0.1$ & 2 \\
Paired t-test RMA $<0.1$ & 2 \\
$\begin{array}{l}\text { No. of MAS } 5.0 \text { 'change calls' (probe } \\
\text { set is rated as decreased or increased) }\end{array}$ & $\begin{array}{c}\text { 1 per 'change call' } \\
\text { (maximum 3) }\end{array}$ \\
Average change of signal log ratio & 2 \\
MAS 5.0 <-0.4 or $>0.4$ & 2 \\
Average change of signal log ratio & \\
RMA <-0.4 or $>0.4$ & 11 \\
Total & \\
\hline
\end{tabular}

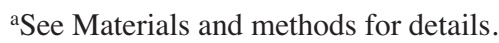

five weeks, colonies ( $\varepsilon 20 \mu \mathrm{m}$ diameter) per field $\left(0.25 \mathrm{~cm}^{2}\right)$ were counted (12 fields/well; magnification x25). Each assay was done in triplicate.

Migration assay. Migration studies were performed using a modified Boyden-Chamber assay (20). Briefly, after a serumstarvation of $24 \mathrm{~h}, 2 \times 10^{5}$ cells were seeded in the upper compartment of the chamber (Blind Well Chamber, Costar, Corning, USA). Fibroblast-conditioned medium was used as chemoattractant and filled in the lower compartment. Both compartments were separated by an uncoated, $8 \mu \mathrm{m}$ Nucleopore filter (Nucleopore Track Etch Membrane, Whatman, Clifton, USA) and a layer of Matrigel (Matrigel Membrane Matrix, Becton-Dickinson, Bedford, CA, USA) on top of the filter. Cells were allowed to migrate for $24 \mathrm{~h}$ in a humidified atmosphere of $5 \% \mathrm{CO}_{2}$ at $37^{\circ} \mathrm{C}$. Filters with migrated cells were stained with hemalaun/eosin (Hemacolor, Merck, Darmstadt, Germany) and quantified by counting 'cells/field' (magnification $\mathrm{x} 125$ ) with five fields per filter. Each assay was done in triplicate.

Microarray analysis. Total RNA was extracted (Nucleospin RNAII) and labeled cRNA was prepared according to the standard Affymetrix protocol using $15 \mu \mathrm{g}$ of total RNA as starting material. The labeled cRNA was hybridized to Human
Genome HG-U133A chips (Affymetrix, Inc., Santa Clara, CA, USA) containing 18,400 transcripts of 14,500 genes. The array analysis was performed three times, each time comparing RNA of cells transfected with EGFR-specific siRNA with RNA of control-siRNA-transfected cells (EGR10 vs. EGR12). For each of the three array analyses, independently generated RNAs were used and the results of the three independent experiments were compared. Microarray data were analyzed by using in parallel Affymetrix Microarray Suite 5.0 (MAS 5.0) software and RMAExpress (Robust Multichip Average, www. stat.berkeley.edu/users/bolstad/RMAExpress/RMAExpress. html). Because of the relatively small changes found in the array analysis, a set of criteria was defined to classify genes as significantly regulated (Table I). Paired t-tests were performed for each probe set using logged MAS 5.0 or logged RMA signal values, respectively. 'Change call' is a MAS 5.0defined output indicating whether a significant expression change is detectable for a given probe set in a pairwise comparison setting (MAS 5.0 baseline comparison analysis). This resulted in a maximum of three points for probe sets displaying significant change calls in all three replicate analyses. Additional points were assigned after calculating average fold change values for both the MAS 5.0 and the RMA expression measures. Since overall changes in expression patterns were relatively small, a threshold of \pm 0.4 was chosen for average signal log ratios (corresponding to a roughly 1.3-fold change). The maximum score added up to 11 points and transcripts with a score of 8 or above were selected for further analysis.

\section{Results}

Inhibition of EGFR protein and $m R N A$ expression by transfection of siRNA. U373 MG and LN18 cells were transiently transfected with different concentrations (0.01-100 nM) of siRNA EGR10 and siRNA EGR12, respectively. The reduction of EGFR protein expression was determined by immunoblot (Fig. 1) and flow cytometric analysis (Fig. 2). With both methods, a specific reduction of EGFR of up to $90 \%$ in U373 MG cells and $70 \%$ in LN18 cells could be demonstrated. Protein down-regulation could be already observed at siRNA concentrations as low as $0.1 \mathrm{nM}$, concentrations above $10 \mathrm{nM}$ did not enhance the effect any further. In time course experiments, down-regulation of protein was shown to last for at least five days (Fig. 2). This could also be demonstrated for EGFR mRNA, which was readily reduced to $20 \%$ after a few hours in U373 MG cells. No attenuation of this effect was observed up to 120-h post-transfection (Fig. 3).

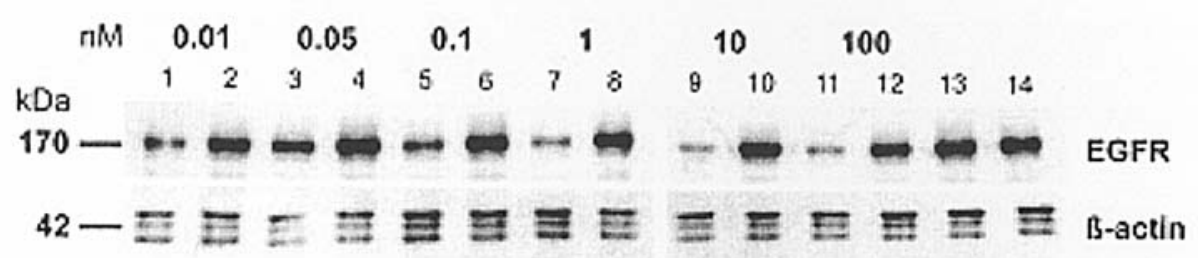

Figure 1. Down-regulation of EGFR protein expression using different siRNA concentrations in U373 MG glioma cells. U373 MG cells were transfected with different concentrations of EGFR-specific siRNA EGR10 (odd numbers) and control siRNA EGR12 (even numbers), respectively: 0.01 nM (lanes 1 and 2), $0.05 \mathrm{nM}$ (lanes 3 and 4), $0.1 \mathrm{nM}$ (lanes 5 and 6), $1 \mathrm{nM}$ (lanes 7 and 8), $10 \mathrm{nM}$ (lanes 9 and 10), 100 nM (lanes 11 and 12), oligofectamine only (lane 13), untreated control (lane 14). 


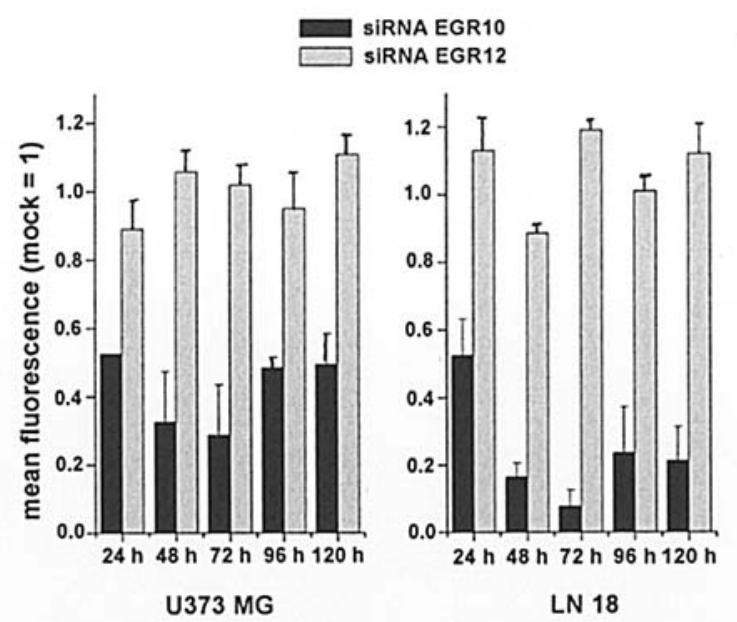

Figure 2. EGFR protein expression at different time points after transfection with $10 \mathrm{nM}$ siRNA. U373 MG and LN18 cells were transfected with either $10 \mathrm{nM}$ of EGFR-specific siRNA EGR10 or control siRNA EGR12, respectively. EGFR expression was determined by flow cytometry. Expression data were normalized to mock-treated controls. Bars represent mean values of four independent experiments, error bars indicate standard deviation.

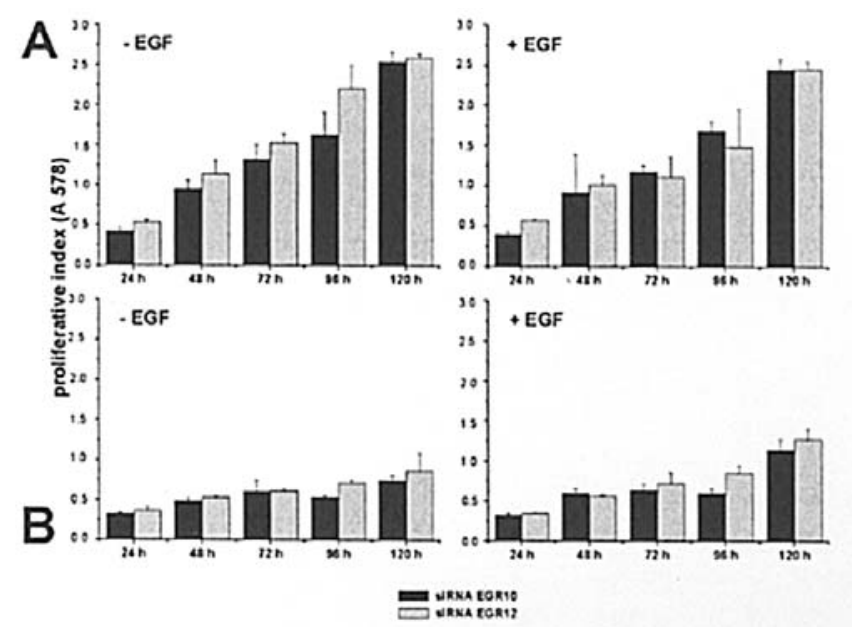

Figure 4. Proliferation of U373 MG cells after transfection with $10 \mathrm{nM}$ siRNA. U373 MG cells were either transfected with $10 \mathrm{nM}$ siRNA EGR10 or siRNA EGR12. (A), Proliferation in the presence of $10 \%$ FCS, with or without addition of EGF (20 ng/ml). (B), Proliferation in the absence of serum, with or without addition of EGF $(20 \mathrm{ng} / \mathrm{ml})$. Proliferative activity was determined by crystal violet staining assay (absorbance at $578 \mathrm{~nm}$ ). Error bars indicate standard deviation.

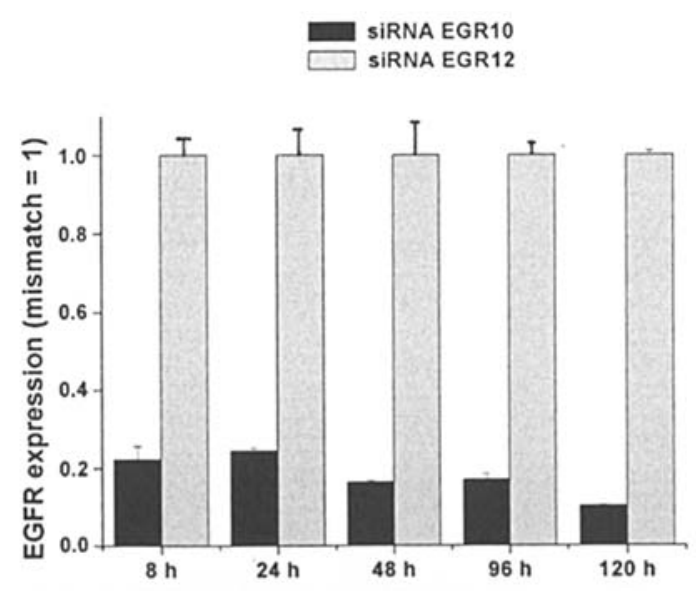

Figure 3. EGFR mRNA expression at different time points after transfection with $10 \mathrm{nM}$ siRNA. U373 MG cells were transfected with either $10 \mathrm{nM}$ of EGFR-specific siRNA EGR10 or control siRNA EGR12, respectively. EGFR mRNA expression was quantified by real-time PCR. Values for EGR10transfected cells were normalized to EGR12-treated controls (EGR12=1). Bars represent mean values of three independent experiments, error bars indicate standard deviation.

Effect of EGFR down-regulation on glioma cell proliferation. To evaluate siRNA-mediated effects, the EGFR-specific tyrosine kinase inhibitor (TKI) AG1478 was used. Initial experiments had demonstrated the inhibition of cell proliferation at a concentration of $20 \mu \mathrm{M}$ AG1478 in both cell lines under investigation (data not shown).

To analyze the effect of siRNA mediated EGFR downregulation on U373 MG and LN18 cells, first their proliferative activity after transfection of siRNAs was tested under multiple culture conditions. The addition of epidermal growth factor (EGF) had been shown to enhance proliferation under serumfree conditions in both cell lines, indicating functional signaling through EGFR (data not shown). Cell proliferation after siRNA transfection was measured in DMEM with and without serum, with or without addition of EGF (20 ng/ml) and with different concentrations of siRNA (1-100 nM). Surprisingly, in none of the experiments an inhibiting effect on cell proliferation could be detected (Figs. 4 and 5).

To elucidate if simultaneous treatment of glioma cells with siRNAs and TKI would result in an enhanced inhibition of cell proliferation by AG1478, the TKI was added 6- and 72-h post-transfection, respectively. No additive effect was detected, inhibition of U373 MG and LN18 proliferation was observed at AG1478 concentrations identical to those in experiments without siRNA transfection (20 $\mu \mathrm{M}$; Fig. 6).

Effect of siRNA transfection on anchorage-independent growth. To determine if the siRNA-mediated down-regulation of EGFR 


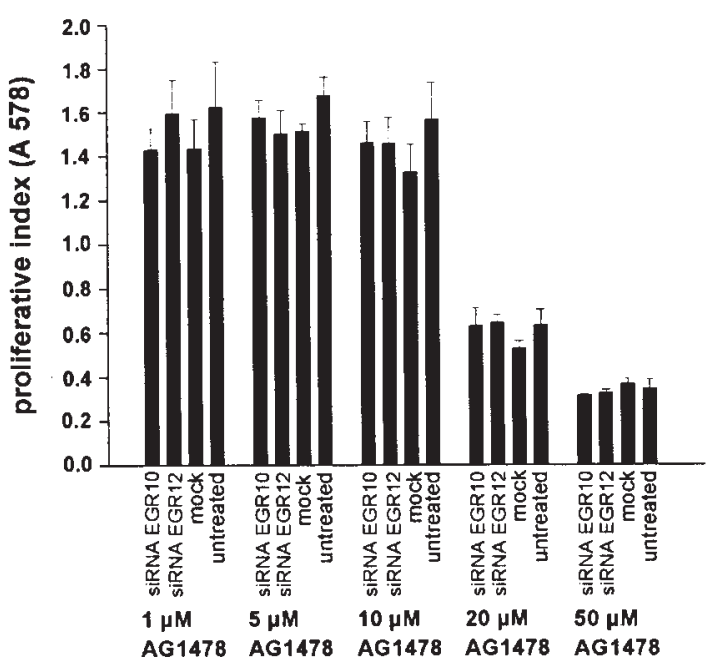

Figure 6. Proliferation of U373 MG cells after transfection of $10 \mathrm{nM}$ siRNA EGR10 and simultaneous treatment with AG1478. U373 cells were transfected with $10 \mathrm{nM}$ siRNA EGR10 and siRNA EGR12 or treated with oligofectamine only (mock). 6-h post-transfection, the transfection medium was replaced with DMEM (10\% FCS) and increasing amounts of AG1478 were added (1-50 $\mu \mathrm{M})$. Proliferation was measured over a period of $120 \mathrm{~h}$; the chart exemplifies cell mass at $96 \mathrm{~h}$. Error bars indicate standard deviation.

would have an inhibiting effect in three-dimensional, rather than in two-dimensional proliferation assays, the capacity of U373 MG cells to form colonies in soft agar was investigated. The cells were routinely transfected with $10 \mathrm{nM}$ of siRNA or pretreated with $20 \mu \mathrm{M}$ of AG1478. 72-h post-transfection, cells were seeded in wells coated with soft agar. AG1478 was added to the supernatant only once at the day of seeding. Colony formation was measured 5 weeks later by microscopically counting colonies with a diameter of $\varepsilon 20 \mu \mathrm{m}$.
No inhibition of colony formation could be observed in samples treated with EGFR-specific siRNA EGR10 compared to EGR12-transfected or oligofectamine-treated controls. In contrast, AG1478 significantly impaired cell growth (Fig. 7).

Effect of siRNA transfection on migration of U373 MG glioma cells. Although no inhibiting effect of siRNA-mediated EGFR depletion on U373 MG or LN18 cells was detectable to this point, it remained possible that EGFR exerted its effect mainly on migratory or invasive properties rather than on proliferative activity. This was tested using a Boyden-Chamber assay where cells migrate through an artificial basement membrane containing different extracellular matrix proteins. Again, transfection with siRNA EGR10 did not cause an inhibitory effect on migration, whereas treatment with AG1478 resulted in a marked decrease in the number of migrated cells (Fig. 8).

Effect of siRNA transfection on EGFR-coupled PKB and ERK1/2 signaling pathways. Since EGFR stimulation by EGF results in activation of two main signaling pathways, by phosphorylation of extracellular regulated kinases (ERK1/2) and protein kinase $\mathrm{B}(\mathrm{PKB})$, the activation status of these molecules after treatment with EGF-specific siRNA or AG1478 was investigated. Whole cell lysates were subjected to immunoblot analysis and the amount of phosphorylated PKB and ERK1/2 was determined. Additionally, the expression of EGFR protein was shown to verify the specific downregulation by siRNA EGR10. Stimulation with EGF resulted in further reduction of receptor by endocytosis and degradation after 15 min (Fig. 9A). Immunoblot analysis revealed that in both cell lines PKB is constitutively activated (Fig. 9C). Accordingly, treatment with EGF did not result in an increase in phosphorylated PKB, whereas activation of ERK1/2 was
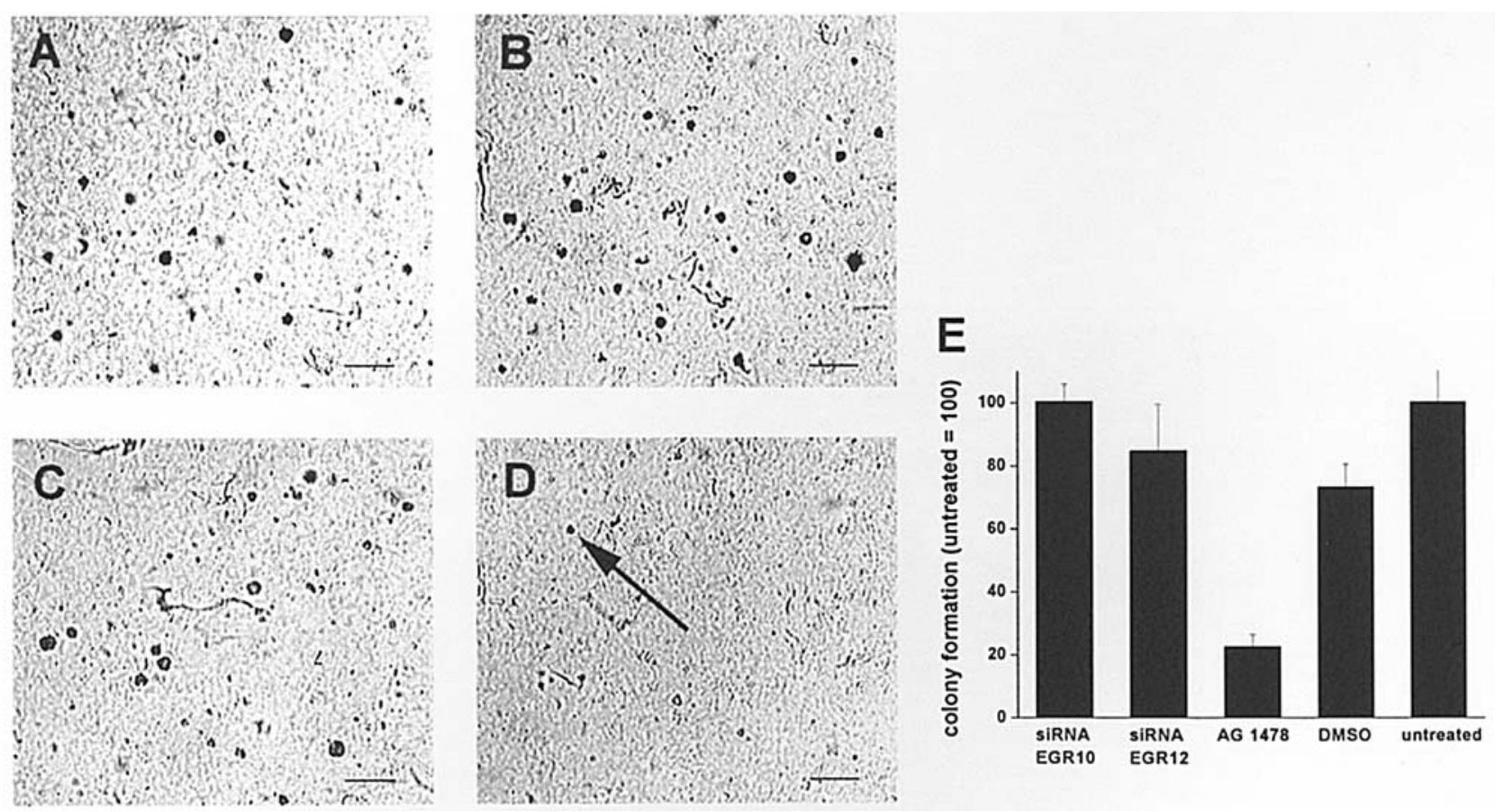

Figure 7. Colony formation of U373 MG cells. U373 cells were either transfected with 10 nM of control siRNA EGR12 (A) or siRNA EGR10 (B) or treated with DMSO (C) and $20 \mu \mathrm{M}$ AG1478 (D), respectively. The arrow in (D) indicates a single small colony; scale bar, $250 \mu \mathrm{m}$. In (E), colony number is depicted relative to untreated controls. Bars represent mean values of three independent experiments, error bars indicate standard deviation. 


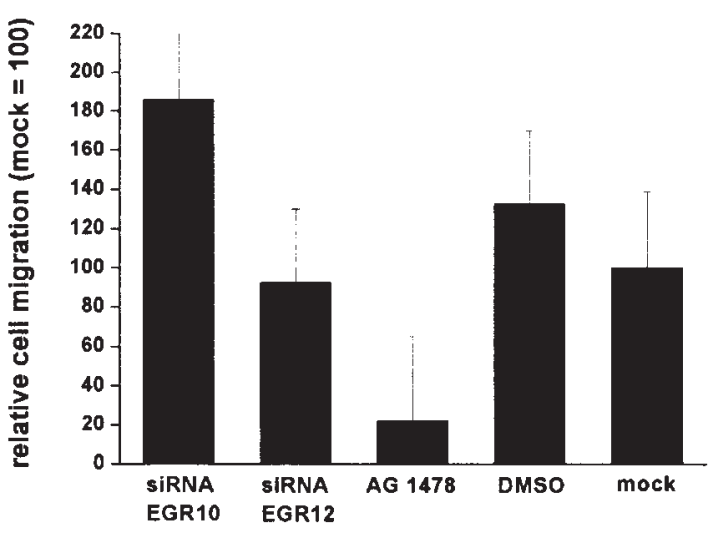

Figure 8. Migration of U373 MG cells. U373 MG cells were transfected with siRNAs EGR10, EGR12 or treated with DMSO or AG1478 $(20 \mu \mathrm{M})$, respectively. 72-h post-transfection, migration was determined by using a modified Boyden-Chamber assay. Each assay was performed in triplicate and the experiment was reproduced twice. Error bars represent standard deviations of the measurements from nine independent samples. markedly enhanced in both cell lines. Similar to the results obtained with proliferation and migration assays, no inhibitory influence on phosphorylation of ERK1/2 and PKB could be observed with siRNA EGR10 (Fig. 9C and G). In contrast, AG1478 treatment caused a significant reduction in phosphoERK and phospho-PKB (Fig. 9E and I).

Effect of siRNA transfection on gene expression in U373 MG cells. In order to get a more comprehensive understanding of the siRNA treatment effects on the molecular level, we performed gene expression analysis on Affymetrix U133A microarrays. U373 MG cells were transfected with $10 \mathrm{nM}$ of siRNA EGR10 or EGR12, respectively. 72-h post-transfection, cells were serum-starved for $24 \mathrm{~h}$ and then stimulated with $100 \mathrm{ng} /$ $\mathrm{ml}$ EGF for $6 \mathrm{~h}$. The experiment was independently performed three times for a total of six arrays (triplicates for siRNA EGR10 and siRNA EGR12 transfection, respectively). Since experiments from different time points formed a tighter cluster than experimental groups (data not shown), a pairwise

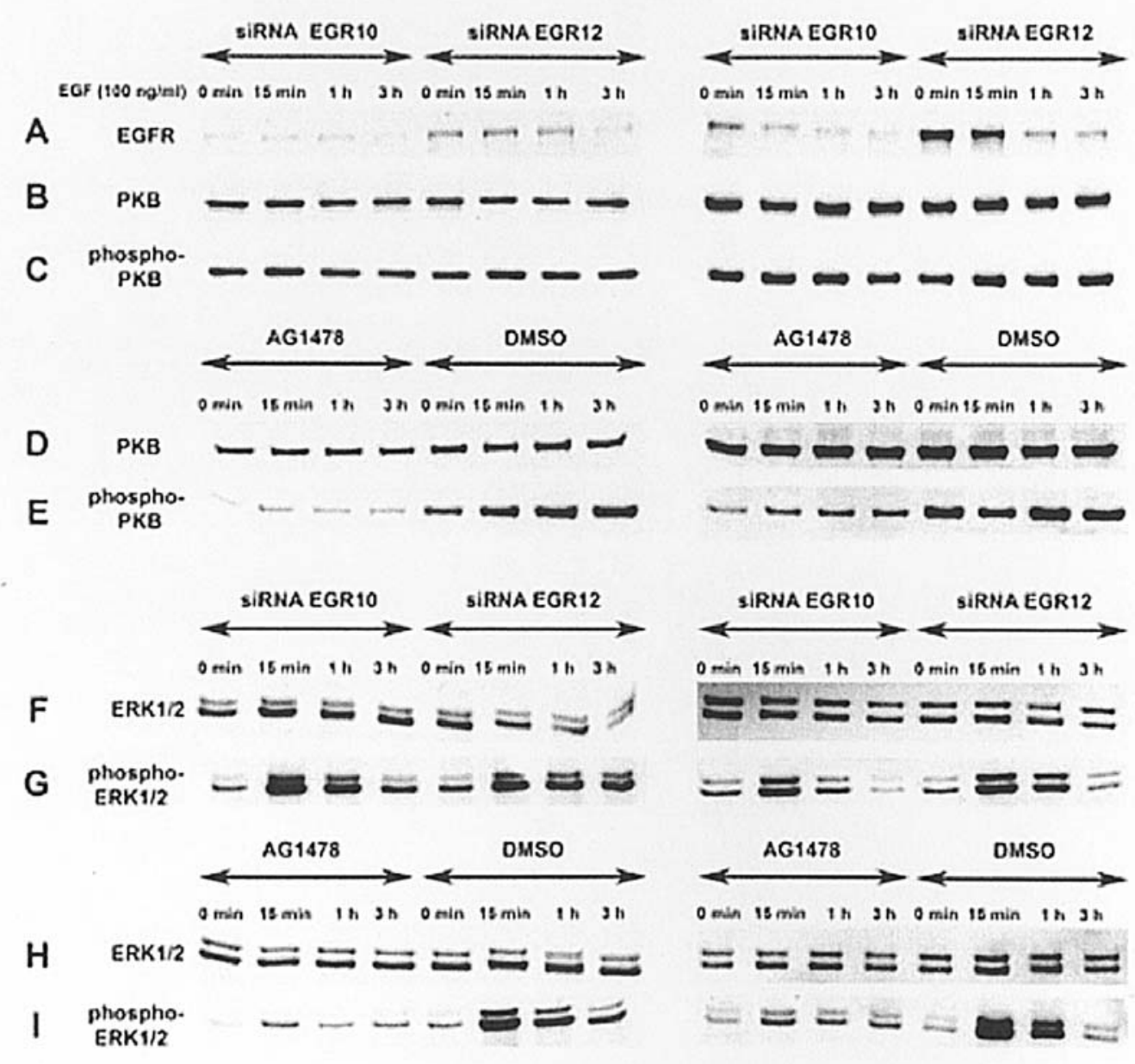

U373 MG

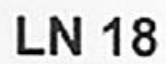

Figure 9. Activation status of protein kinase B (PKB/AKT) and mitogen-activated protein kinases (ERK1/2) in U373 MG and LN18 glioma cells. U373 MG and LN18 cells were transfected with siRNA EGR10 or siRNA EGR12 (10 nM f.c.) or treated with DMSO or AG1478 (20 $\mu$ M f.c.). 72 -h post-transfection, cells were serum starved for $24 \mathrm{~h}$ and then EGF $(100 \mathrm{ng} / \mathrm{ml})$ was added. At the indicated time points, whole cell lysates were prepared and samples were subjected to immunoblot analysis. Activation of PKB and ERK1/2 was detected by phospho-specific antibodies, total PKB and ERK1/2 expression were used as controls. (A), EGFR-expression after transfection with siRNA EGR10 or EGR12. (B), Unphosphorylated PKB after transfection with siRNAs EGR10, EGR12. (C), Phospho-PKB after transfection with siRNAs EGR10, EGR12. (D), Unphosphorylated PKB after treatment with AG1478 or DMSO. (E), Phospho-PKB after treatment with AG1478, DMSO. (F), Unphosphorylated ERK1/2 after transfection with siRNAs EGR10, EGR12. (G), Phospho-ERK1/2 after transfection with siRNAs EGR10, EGR12. (H), Unphosphorylated ERK1/2 after treatment with AG1478, DMSO. (I), Phospho-ERK1/2 after treatment with AG1478, DMSO. 


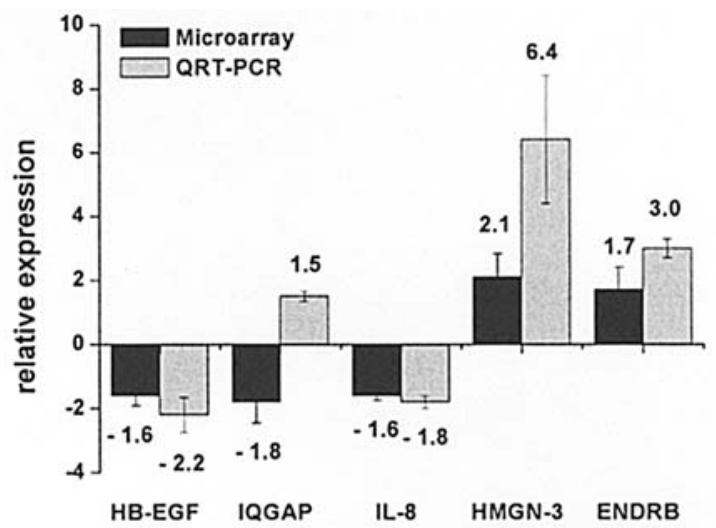

Figure 10 . Validation of microarray data by quantitative real-time PCR. Three down-regulated and two up-regulated genes were randomly chosen for confirmation of microarray results by TaqMan real-time PCR as described in Materials and methods. Values for each gene were normalized to expression levels of GAPDH and ratios comparing expression in siRNA EGR10 and control siRNA EGR12 transfected cells were calculated. Bars represent mean values of three PCR experiments and three independent microarray analyses, respectively. Error bars indicate standard deviation.

comparison was conducted. Transcripts which were undetectable in all six arrays (i.e., which had 'Absent' calls assigned to them by the MAS 5.0 software) were eliminated from data analysis; all other transcripts were analyzed according to the criteria defined in Table I. Using this set of parameters, a total of 103 transcripts representing 95 genes were found to be reproducibly regulated, with up-regulation of 44 genes and down-regulation of 51 genes (Table II).

The overall difference in expression patterns between siRNA EGR10-transfected and control-transfected cells was only diminutive. EGFR itself represented the most prominently altered transcript with a 5-fold change (RMA value), equivalent to a down-regulation of $80 \%$. This was in very good accordance with the results obtained in the real-time PCR experiments, indicating the general validity of the microarray analyses. That is further supported by the identification of genes whose transcription is coupled to EGFR-signaling, e.g., the EGFRspecific ligand heparin-binding EGF (HB-EGF, DTR) (21), or urokinase plasminogen activator receptor (UPAR, PLAUR) (22), which is able to transactivate EGFR (23) and is upregulated in highly malignant glioma (24). Some of the downregulated transcripts play a role in cellular migration and invasion (DDEF1, ESDN, FN, HMGA1, IQGAP, ITGA7, PTHLH, TIAM1, TNC, UPAR), others are proliferationpromoting (FOSL2, FOXM1B, MAP2K3, TCF7L2) or antiapoptotic (BCL2L, MCL1). The induced transcripts form a highly heterogeneous group. In addition to a few proapoptotic genes (TNFRSF10B, PCD2), DNA- and RNA-binding transcripts were up-regulated (ANKT, SCA1, SMARCA1 and PAIP1, SSB, THOC2, SFRS7, respectively), as well as some genes coding for proteins associated with the extracellular matrix (COL XI 1A, ALCAM, IGSF4, EFEMP1).

Validation of microarray data by quantitative real-time PCR. To corroborate the results obtained in the microarray experiments, the expression levels of five exemplary genes (DTR, IQGAP, IL-8, HMGN3, EDNRB) were determined by quantitative real-time PCR (QRT-PCR) with newly generated RNA samples, i.e., a different cDNA from those used in the three microarray experiments was used for the QRT-PCR. For 4 of the 5 genes, the observed regulations were confirmed both qualitatively and quantitatively; only the down-regulation of IQGAP was irreproducible (Fig. 10). This remarkable degree of congruence between the two methods validates our scoring approach and suggests that the majority of the 95 genes listed in Table I are indeed affected by the EGFR siRNA treatment.

\section{Discussion}

In this report we have examined the effect of siRNA-mediated, specific down-regulation of EGFR on human malignant glioma cell lines U373 MG and LN18. The substantial reduction of about $80 \%$ of EGFR protein and mRNA expression was demonstrated (Figs. 1-3 and 9A). However, no inhibitory effect on cell proliferation could be observed (Figs. 4-7). Likewise, cell cycle analysis by flow cytometry showed no reduction in S-phase fraction or increase in the G1- or G2-arrested cell fraction (data not shown). Since it has been repeatedly demonstrated that EGF might enhance cellular responses like migration and invasion rather than stimulating proliferative activity $(25,26)$, migration of U373 MG cells after siRNA transfection was investigated (Fig. 9). Again, no inhibitory effect was detectable. Similar results were obtained by determining the phosphorylation status of members of downstream signaling cascades (PKB, ERK1/2, Fig. 9). In contrast to these findings, treatment of U373 MG and LN18 cells with the tyrphostin AG1478 caused inhibition of proliferation and migration and reduced activation of effector molecules. AG1478 is known as a selective inhibitor of EGFR, with up to $10^{4}$-fold higher $\mathrm{IC}_{50}$ values for other tyrosine kinases (27; Calbiochem product data sheet) and it is widely used in glioma in vitro studies (28-30). Nevertheless, Lipson et al reported unspecific inhibition of platelet-derived growth factor receptor (PDGFR) at concentrations above $10 \mu \mathrm{M}$ AG1478 (31). AG1478 belongs to the same class of synthetic tyrosine kinase inhibitors as Gefitinib ('Iressa', ZD1839), the first FDAapproved EGFR-targeting drug (32). As for AG1478, no specifications exist concerning the influence of Gefitinib on receptor tyrosine kinases (RTK's) besides EGFR. However, investigations with fibroblasts and endothelial cells showed blocking of insulin-like growth factor (IGF) and plateletderived growth factor (PDGF) induced proliferation at concentrations similar to those at which EGF-induced proliferation was inhibited (32). Since these values are within the range of clinically relevant plasma concentrations of Gefitinib (32), the observed cytotoxic effects after treatment might result from concomitant inhibition of EGFR and other receptor tyrosine kinases like IGF1R and PDGFR. Since AG1478 and Gefitinib belong to the same class of substances and a high concentration $(20 \mu \mathrm{M})$ of AG1478 is needed to induce inhibitory effects in U373 MG and LN18 glioma cells, unspecific effects similar to those seen with Gefitinib can not be excluded.

In accordance with our previous results, transfection of U373 MG cells with siRNA EGR10 resulted in marked downregulation of EGFR transcript, but only a marginal effect 
Table II. Expression of 95 genes regulated in U373 MG cells after transfection with EGFR-specific siRNA EGR10.

\begin{tabular}{|c|c|c|c|c|}
\hline $\begin{array}{l}\text { Gene } \\
\text { symbol }\end{array}$ & Title & $\begin{array}{l}\text { Average fold change } \\
\text { (RMA/MAS) }\end{array}$ & $\begin{array}{c}\text { p-value } \\
\text { (RMA/MAS) }\end{array}$ & Score \\
\hline EGFR & Epidermal growth factor receptor & $-4.98 /-4.29$ & $0.012 / 0.008$ & 11 \\
\hline ARHI & Ras homolog gene family member 1 & $-1.97 /-1.95$ & $0.037 / 0.076$ & 10 \\
\hline ALDH1A3 & Aldehyd dehydrogenase family member A3 & $-1.79 /-1.91$ & $0.038 / 0.039$ & 11 \\
\hline IQGAP1 & IQ motif containing GTPase activating protein 1 & $-1.77 /-2.0$ & $0.005 / 0.001$ & 10 \\
\hline DUSP5 & Dual specifity phosphatase 5 & $-1.75 /-1.74$ & $0.048 / 0.004$ & 10 \\
\hline ESDN & Endothelial and smooth muscle cell-derived neuropilin-like protein & $-1.68 /-2.19$ & $0.196 / 0.067$ & 8 \\
\hline MCL1 & Myeloid cell leukemia sequence 1 (BCL2-related) & $-1.66 /-1.41$ & $0.095 / 0.101$ & 8 \\
\hline PTPN12 & Protein tyrosine phosphatase, non-receptor type 12 & $-1.65 /-1.55$ & $0.08 / 0.066$ & 10 \\
\hline MAP4K4 & Mitogen-activated protein kinase kinase kinase kinase 4 & $-1.6 /-1.41$ & $0.175 / 0.1$ & 9 \\
\hline IL8 & Interleukin 8 & $-1.59 /-1.41$ & $0.036 / 0.09$ & 10 \\
\hline P37NB & $37 \mathrm{kDa}$ leucine rich repeat protein & $-1.58 /-1.7$ & $0.023 / 0.194$ & 8 \\
\hline PLXNA1 & Plexin A1 & $-1.58 /-1.87$ & $0.033 / 0.001$ & 11 \\
\hline HSMPP8 & M-phase phosphoprotein mpp8 & $-1.56 /-1.48$ & $0.007 / 0.024$ & 10 \\
\hline RIS1 & Ras-induced senescence 1 & $-1.55 /-2.05$ & $0.039 / 0.101$ & 8 \\
\hline DTR & $\begin{array}{l}\text { Diphteria toxin receptor (heparin-binding epidermal growth } \\
\text { factor-like growth factor, HB-EGF) }\end{array}$ & $-1.55 /-1.82$ & $0.21 / 0.01$ & 11 \\
\hline LIF & Leukemia-inhibitory factor & $-1.49 /-1.59$ & $0.027 / 0.062$ & 9 \\
\hline CDC42BPB & CDC42 binding protein kinase beta (DMPK-like) & $-1.49 /-1.38$ & $0.147 / 0.042$ & 8 \\
\hline SYBL1 & Synaptobrevin-like 1 & $-1.49 /-1.48$ & $0.113 / 0.091$ & 9 \\
\hline PHLDA1 & Pleckstrin homology-like domain, family A member 1 & $-1.48 /-2.52$ & $0.101 / 0.099$ & 8 \\
\hline DDEF1 & Development and differentiation enhancing factor 1 & $-1.48 /-1.52$ & $0.015 / 0.074$ & 11 \\
\hline FOSL2 & FOS-like antigen 2 & $-1.47 /-1.35$ & $0.096 / 0.052$ & 10 \\
\hline PTHLH & Parathyroid hormone-like hormone & $-1.45 /-1.35$ & $0.074 / 0.045$ & 10 \\
\hline MAP2K3 & Mitogen-activated protein kinase kinase 3 & $-1.43 /-1.52$ & $0.047 / 0.121$ & 9 \\
\hline PLAUR & Plasminogen activator, urokinase receptor & $-1.43 /-1.32$ & $0.012 / 0.047$ & 10 \\
\hline FN1 & Fibronectin 1 & $-1.42 /-1.35$ & $0.045 / 0.019$ & 10 \\
\hline TCF7L2 & Transcription factor 7 -like 2/TCF 4 & $-1.42 /-1.26$ & $0.058 / 0.067$ & 8 \\
\hline SPRY4 & Sprouty homolog 4 (Drosophila) & $-1.41 /-1.52$ & $0.051 / 0.072$ & 10 \\
\hline HMGA1 & High mobility group AT-hook 1 & $-1.41 /-1.7$ & $0.009 / 0.206$ & 9 \\
\hline SFRP1 & Secreted frizzled-related protein 1 & $-1.41 /-1.38$ & $0.05 / 0.045$ & 10 \\
\hline FOXM1 & Forkhead box M1 & $-1.4 /-1.38$ & $0.255 / 0.088$ & 8 \\
\hline RBPMS & RNA binding protein with multiple splicing & $-1.38 /-1.41$ & $0.016 / 0.065$ & 8 \\
\hline ITGA7 & Integrin alpha 7 & $-1.38 /-1.59$ & $0.183 / 0.094$ & 8 \\
\hline CPA4 & Carboxypeptidase A4 & $-1.37 /-1.45$ & $0.199 / 0.036$ & 8 \\
\hline SLC5A3 & Solute carrier family 5 (inositol transporters) member 3 & $-1.36 /-1.29$ & $0.003 / 0.03$ & 8 \\
\hline SHC1 & SHC (Src homology 2 domain containing transforming protein) & $-1.35 /-1.29$ & $0.026 / 0.029$ & 8 \\
\hline DCTN1 & Dynactin 1 & $-1.35 /-1.55$ & $0.169 / 0.079$ & 8 \\
\hline $\mathrm{SAC} 2$ & Sac domain-containing inositol phosphatase 2 & $-1.35 /-1.35$ & $0.216 / 0.089$ & 8 \\
\hline BCL2L1 & BCL2-like 1 & $-1.35 /-1.48$ & $0.053 / 0.076$ & 9 \\
\hline TIAM1 & T-cell lymphoma invasion and metastasis 1 & $-1.34 /-1.32$ & $0.025 / 0.075$ & 10 \\
\hline PITPN & Phosphatidylinositol transfer protein & $-1.34 /-1.23$ & $0.014 / 0.07$ & 8 \\
\hline DUSP6 & Dual specifity phosphatase 6 & $-1.34 /-2.09$ & $0.006 / 0.068$ & 11 \\
\hline p66alpha & p66alpha & $-1.29 /-1.35$ & $0.018 / 0.086$ & 8 \\
\hline TNC & Tenascin $\mathrm{C}$ & $-1.27 /-1.32$ & $0.04 / 0.026$ & 8 \\
\hline FLJ12750 & & $-1.27 /-1.41$ & $0.006 / 0.048$ & 8 \\
\hline RAB31 & RAB31 member RAS oncogene family & $-1.25 /-1.32$ & $0.05 / 0.044$ & 8 \\
\hline ETS2 & v-ets erythroblastosis virus E26 oncogene homolog 2 & $-1.24 /-1.32$ & $0.053 / 0.01$ & 8 \\
\hline MET & Met proto-oncogene (hepatocyte growth factor receptor) & $-1.24 /-1.35$ & $0.051 / 0.079$ & 8 \\
\hline
\end{tabular}


Table II. Continued.

\begin{tabular}{|c|c|c|c|c|}
\hline $\begin{array}{l}\text { Gene } \\
\text { symbol }\end{array}$ & Title & $\begin{array}{l}\text { Average fold change } \\
\quad(\mathrm{RMA} / \mathrm{MAS})\end{array}$ & $\begin{array}{c}\text { p-value } \\
\text { (RMA/MAS) }\end{array}$ & Score \\
\hline INPP5A & Inositol phosphatase-5-phosphatase, $40 \mathrm{kDa}$ & $-1.23 /-1.32$ & $0.001 / 0.047$ & 8 \\
\hline NR1D1 & Nuclear receptor subfamily 1, group D, member 1 & $-1.22 /-2.09$ & $0.011 / 0.035$ & 8 \\
\hline P4HA2 & Procollagen-proline, 2-oxoglutarate 4-dioxygenase & $1.25 / 1.35$ & $0.058 / 0.072$ & 8 \\
\hline NUDT9 & Nudix (nucleoside diphosphate linked moiety X) type motif 9 & $1.32 / 1.41$ & $0.221 / 0.063$ & 8 \\
\hline ANXA1 & Annexin A1 & $1.34 / 1.38$ & $0.011 / 0.004$ & 10 \\
\hline AKR1C1 & Aldo-keto reductase family 1 member $\mathrm{C} 1$ & $1.34 / 1.45$ & $0.081 / 0.153$ & 8 \\
\hline SFRS7 & Splicing factor, arginine/serine-rich $7,35 \mathrm{kDa}$ & $1.34 / 1.35$ & $0.107 / 0.038$ & 8 \\
\hline SMARCA1 & $\begin{array}{l}\text { SW1/SNF related, matrix-associated, actin-dependent regulator } \\
\text { of chromatin, subfamily A member } 1\end{array}$ & $1.35 / 2.7$ & $0.014 / 0.046$ & 8 \\
\hline DUT & DUTP pyrophosphatase & $1.35 / 1.45$ & $0.052 / 0.015$ & 10 \\
\hline ANKT & Nucleolar protein 1 & $1.35 / 1.38$ & $0.002 / 0.056$ & 10 \\
\hline MYLK & Myosin light polypeptide kinase & $1.36 / 1.45$ & $0.074 / 0.032$ & 10 \\
\hline NUP88 & Nucleoporin $88 \mathrm{kDa}$ & $1.38 / 1.35$ & $0.099 / 0.089$ & 9 \\
\hline HEBP2 & Heme binding protein 2 & $1.41 / 1.35$ & $0.05 / 0.026$ & 9 \\
\hline CREG & Cellular repressor of E1A-stimulated genes & $1.41 / 1.32$ & $0.07 / 0.096$ & 10 \\
\hline EFEMP1 & EGF-containing fibulin-like extracellular matrix protein 1 & $1.41 / 1.38$ & $0.004 / 0.01$ & 11 \\
\hline FLJ12671 & & $1.41 / 1.48$ & $0.014 / 0.028$ & 9 \\
\hline ALCAM & Activated leukocyte cell adhesion molecule & $1.41 / 1.41$ & $0.002 / 0.056$ & 9 \\
\hline SERPINA3 & Serine (or cysteine) proteinase inhibitor, clade A, member 3 & $1.42 / 1.32$ & $0.388 / 0.012$ & 8 \\
\hline PDCD2 & Programmed cell death 2 & $1.42 / 1.41$ & $0.074 / 0.218$ & 8 \\
\hline CSPG6 & Chondroitin sulfate proteoglycan 6 (Bamacan) & $1.42 / 1.48$ & $0.219 / 0.096$ & 8 \\
\hline RARG-1 & Retinoic acid repressible protein & $1.44 / 1.32$ & $0.021 / 0.044$ & 8 \\
\hline OAZ1 & Ornithine decarboxylase antizyme 1 & $1.44 / 1.38$ & $0.026 / 0.02$ & 10 \\
\hline HBLD2 & HESB-like domain containing 2 & $1.45 / 1.45$ & $0.082 / 0.105$ & 8 \\
\hline C6ORF111 & Chromosome 6 open reading frame 111 & $1.45 / 1.48$ & $0.025 / 0.156$ & 9 \\
\hline ARL5 & ADP-ribosylation factor-like 5 & $1.46 / 1.45$ & $0.036 / 0.115$ & 8 \\
\hline $\mathrm{DMN}$ & Desmuslin & $1.46 / 1.38$ & $0.074 / 0.141$ & 8 \\
\hline GPC4 & Glypican 4 & $1.46 / 1.35$ & $0.068 / 0.07$ & 10 \\
\hline TNFRSF10B & Tumor necrosis factor receptor superfamily, member $10 \mathrm{~b}$ & $1.47 / 1.45$ & $0.017 / 0.069$ & 11 \\
\hline SSB & Sjogren syndrome antigen B (autoantigen La) & $1.48 / 1.52$ & $0.086 / 0.039$ & 11 \\
\hline SCRG1 & Scrapie responsive protein 1 & $1.48 / 1.41$ & $0.097 / 0.138$ & 8 \\
\hline IGSF4 & Immunoglobulin superfamily, member 4 & $1.49 / 1.45$ & $0.018 / 0.023$ & 9 \\
\hline THOC2 & THO complex & $1.53 / 1.35$ & $0.016 / 0.026$ & 10 \\
\hline TOP2A & Topoisomerase (DNA) II alpha $170 \mathrm{kDa}$ & $1.54 / 1.55$ & $0.069 / 0.047$ & 11 \\
\hline SCA1 & Spinocerebellar ataxia 1 & $1.58 / 1.7$ & $0.034 / 0.069$ & 11 \\
\hline S164 & S 164 protein & $1.61 / 1.62$ & $0.074 / 0.055$ & 10 \\
\hline MYCBP & c-myc binding protein & $1.64 / 1.66$ & $0.019 / 0.161$ & 9 \\
\hline AKR1B10 & Aldo-keto-reductase family 1 , member B10 & $1.65 / 1.59$ & $0.1 / 0.056$ & 8 \\
\hline EDNRB & Endothelin receptor type B & $1.65 / 1.48$ & $0.002 / 0.084$ & 11 \\
\hline CUTL1 & Cut-like 1, CCAAT displacement protein (Drosophila) & $1.67 / 1.59$ & $0.057 / 0.038$ & 11 \\
\hline CDC10 & CDC10 cell division cycle 10 homolog & $1.69 / 1.59$ & $0.011 / 0.022$ & 11 \\
\hline COL11A1 & Collagen type XI, alpha 1 & $1.69 / 1.74$ & $0.088 / 0.121$ & 8 \\
\hline FABP7 & Fatty-acid binding protein 7 , brain & $1.74 / 1.66$ & $0.035 / 0.104$ & 9 \\
\hline ARL6IP & ADP-ribosylation factor-like 6 interacting protein & $1.9 / 1.74$ & $0.09 / 0.125$ & 8 \\
\hline PAIP1 & Polyadenylate binding protein interacting protein 1 & $1.93 / 2.0$ & $0.068 / 0.049$ & 11 \\
\hline HMGN3 & High mobility group nucleosomal binding domain 3 & $2.05 / 2.0$ & $0.081 / 0.142$ & 9 \\
\hline
\end{tabular}

${ }^{\mathrm{a}}$ Genes are listed in ascending order from most down-regulated to strongest up-regulated transcript. See Materials and methods and Table I caption for details on the scoring system. 
on overall gene expression was observed in microarray studies. However, the results strongly suggest that the detected differences between the EGR10 and the control group were indeed attributable to altered EGFR transcription, since several differentially regulated genes are coupled to EGFR-dependent signaling. For example, expression of DTR, PTHLH, UPAR and IL- 8 has been shown to be induced by EGF $(21,22,33,34)$. Additionally, DDEF1 is involved in EGFR recycling (35), the invasion-promoting TNC might function as membranebound EGFR ligand (36) and one of the main adaptor proteins for EGFR, SHC1, was also slightly repressed. The activation of transcription factor TCF4 is also coupled to EGF (37). FOXM1B, another repressed transcription factor has been shown to be up-regulated specifically in highly malignant forms of glioma $(38,39)$. In agreement with reports postulating a tumor-promoting effect of EGFR through enhancement of migration rather than proliferation, quite a few of the 51 down-regulated transcripts play a role in cellular invasion and migration. However, these small, albeit reproducible, effects on the transcript level do not translate into changes of corresponding cellular parameters, like adhesion to matrix proteins (data not shown) or migration through an artificial basement membrane (Fig. 8). It is possible that the small changes in expression do not result in sufficiently reduced amounts of protein. Transcriptional up-regulation was found for 41 genes. As opposed to the group of repressed transcripts, no significant functional relation between the induced transcripts could be established. Some of them are related to the transcription factor myc, e.g., MYCBP, which enhances transcriptional activity of myc (40), the RNA-binding SCA1 (41), and ARL6IP, which belongs to the ARF-family of GTP-binding proteins (42). Of note, EDNRB, a G-protein-coupled receptor (GPCR), was among the most strongly up-regulated transcripts. EDNRB is known to be highly expressed in glioma cells, where binding of its ligand endothelin-1 (ET-1) mediates proangiogenetic and antiapoptotic stimuli (43). Since EDNRB is known to transactivate EGFR (44), one could speculate about a compensation mechanism for the down-regulation of EGFR by induction of EDNRB. The results obtained by the microarray analyses were confirmed by quantitative real-time PCR. For four of five randomly chosen genes, the results of the QRT-PCR were in agreement with the microarray results, although the expression differences were generally more pronounced in the PCR, an observation also made by other investigators (45). For one transcript (IQGAP), the down-regulation found in the microarray could not be confirmed. Since for the QRTPCR analysis a new transfection experiment was conducted, the reproducibility of four genes with relatively low expression differences strongly argues for the general validity of the microarray results.

Although altered EGFR expression is a hallmark of glioma pathogenesis, only very limited information is available on the application of EGFR-targeting drugs like small tyrosine kinase inhibitors (e.g., Gefitinib, Erlotinib) and antibodies (e.g., Cetuximab) in these tumors. One study of Cetuximab in glioma cells showed that application of the substance caused cell cycle arrest and enhanced apoptosis only in cell lines with EGFR gene amplification (46). Halatsch et al (47) report that sensitivity to Erlotinib in glioma cells is independent of EGFR expression level and significantly higher concentrations of inhibitor were needed to block proliferation compared to other tumor cell lines (e.g., colon carcinoma, head and neck tumors). Little more literature is available on the use of Gefitinib in glioma. While apoptosis was enhanced at simultaneous Gefitinib treatment and radiation (48), no inhibitory effect on proliferation was seen with Gefitinib alone (49). In a phase II clinical study, no objective response to Gefitinib in patients with recurrent glioblastoma multiforme could be demonstrated (50). A hint to what might cause these weak effects could be deduced from the work of Li et al (51), who demonstrated effective inhibition of EGFR phosphorylation at low concentrations of Gefitinib, but no concomitant effect on EGFRcoupled signaling. Much higher concentrations were needed to inhibit PKB and ERK1/2, although this effect could not be explained and might perhaps be attributed to unspecific effects. The undiminished signaling through PKB and ERK1/2 might be due to their redundant activation by other receptor tyrosine kinases, for example through members of the ErbB family, e.g., ErbB2. By immunoblot analysis, U373 MG and LN18 cells were shown to express ErbB2 (data not shown), with especially high expression in the U373 MG line. However, upon stimulation with EGF, no phosphorylation of ErbB2 could be detected (data not shown). Likewise, no inhibition of proliferation could be achieved by blocking ErbB2 with the specific TKI AG825, and concomitant application of AG825 with AG1478 or with siRNA EGR10 did not result in enhanced inhibition of proliferation (data not shown). These results indicate that an assumed signaling through the ErbB2 portion of EGFR-ErbB2 heterodimers or through ErbB2 homodimers is not responsible for the observed resistance of the investigated glioma cells to EGFR inhibition. This is in accordance with results of $\mathrm{Li}$ et al who found that simultaneous inhibition of EGFR and ErbB2 had no additive effect in reducing $\mathrm{PKB}$ and ERK1/2 activation (51). U373 MG cells were shown to have no detectable expression of ErbB3 and ErbB4 (52), so it can be excluded that one of the ErbBreceptors is compensating for the decreased EGFR. Increased signaling through IFG1R has been implicated in mediating resistance to AG1478 in glioma cell lines (28). Since U373 MG cells express IGF1R (LN18 show only very weak expression; data not shown), this might represent a mechanism by which these cells make up for diminished EGFR signaling. Nevertheless, it can not be ruled out that the EGFR remaining after siRNA transfection is still sufficient to mediate signaling. However, this is contrary to assumptions made by two different research groups, who proposed a threshold for functional EGFR signaling, since they observed inhibition of proliferation despite a residual amount of EGFR protein of up to $30 \%$ after transfection with siRNAs $(53,54)$. Taken together, the results presented in this study demonstrate that the specific, siRNAmediated down-regulation of EGFR has no impact on the malignant phenotype of the investigated glioma cells.

First results of clinical studies on the application of EGFR-targeting therapeutics in human glioma are now being published (50). Further advanced trials in other types of tumors yielded rather disappointing results, which has been attributed to wrong dosage or combination of drugs and to a lack of patient selection in particular (55). This notion is further supported by recent findings showing that responsiveness to Gefitinib in non-small cell lung cancer depends on mutations 
in the EGFR gene $(56,57)$. The high specificity of siRNAs, as verified here by gene expression profiling, makes them a valuable tool to validate potential therapeutic targets. Regarding our in vitro results and taking into account recent observations on the lack of prognostic significance of EGFR status in glioma patients (58), the role of EGFR as a single target for therapeutic approaches should be reconsidered. By defining subsets of glioma susceptible to EGFR inhibition and through combination with other treatment options, the application of siRNA might yet prove useful as a highly specific tool to modulate the tumor-promoting effects mediated by this receptor.

\section{Acknowledgements}

We would like to thank Drs Bernd Becker and Gerhard Giegerich for help with quantitative real-time PCR and discussion of the microarray analyses and Dr Günther Bernhard for support on the cell proliferation assay.

\section{References}

1. Stupp R, Mason WP, van den Bent MJ, Weller M, Fisher B, Taphoorn MJ, Belanger K, Brandes AA, Marosi C, Bogdahn U, Curschmann J, Janzer RC, Ludwin SK, Gorlia T, Allgeier A, Lacombe D, Cairncross JG, Eisenhauer E and Mirimanoff RO: Radiotherapy plus concomitant and adjuvant temozolomide for glioblastoma. N Engl J Med 352: 987-996, 2005.

2. Libermann TA, Nusbaum HR, Razon N, Kris R, Lax I, Soreq H, Whittle N, Waterfield MD, Ullrich A and Schlessinger J: Amplification, enhanced expression and possible rearrangement of EGF receptor gene in primary human brain tumours of glial origin. Nature 313: 144-147, 1985.

3. Wong AJ, Bigner SH, Bigner DD, Kinzler KW, Hamilton SR and Vogelstein B: Increased expression of the epidermal growth factor receptor gene in malignant gliomas is invariably associated with gene amplification. Proc Natl Acad Sci USA 84: 6899-6903, 1987.

4. Ekstrand AJ, James CD, Cavenee WK, Seliger B, Pettersson RF and Collins VP: Genes for epidermal growth factor receptor, transforming growth factor alpha, and epidermal growth factor and their expression in human gliomas in vivo. Cancer Res 51: 2164-2172, 1991.

5. Frederick L, Wang XY, Eley G and James CD: Diversity and frequency of epidermal growth factor receptor mutations in human glioblastomas. Cancer Res 60: 1383-1387, 2000.

6. Yarden Y and Sliwkowski MX: Untangling the ErbB signalling network. Nat Rev Mol Cell Biol 2: 127-137, 2001.

7. Hackel PO, Zwick E, Prenzel N and Ullrich A: Epidermal growth factor receptors: critical mediators of multiple receptor pathways. Curr Opin Cell Biol 11: 184-189, 1999.

8. Prenzel N, Fischer OM, Streit S, Hart S and Ullrich A: The epidermal growth factor receptor family as a central element for cellular signal transduction and diversification. Endocr Relat Cancer 8: 11-31, 2001.

9. Jorissen RN, Walker F, Pouliot N, Garrett TP, Ward CW and Burgess AW: Epidermal growth factor receptor: mechanisms of activation and signalling. Exp Cell Res 284: 31-53, 2003.

10. Mishima K, Johns TG, Luwor RB, Scott AM, Stockert E, Jungbluth AA, Ji XD, Suvarna P, Voland JR, Old LJ, Huang HJ and Cavanee WK: Growth suppression of intracranial xenografted glioblastomas overexpressing mutant epidermal growth factor receptors by systemic administration of monoclonal antibody (mAb) 806, a novel monoclonal antibody directed to the receptor. Cancer Res 61: 5349-5354, 2001.

11. Wakeling AE: Epidermal growth factor receptor tyrosine kinase inhibitors. Curr Opin Pharmacol 2: 382-387, 2002.

12. Halatsch ME, Schmidt U, Botefur IC, Holland JF and Ohnuma T: Marked inhibition of glioblastoma target cell tumorigenicity in vitro by retrovirus-mediated transfer of a hairpin ribozyme against deletion-mutant epidermal growth factor receptor messenger RNA. J Neurosurg 92: 297-305, 2000.

13. Sugawa N, Ueda S, Nakagawa Y, Nishino H, Nosaka K, Iwashima A and Kurimoto M: An antisense EGFR oligodeoxynucleotide enveloped in Lipofectin induces growth inhibition in human malignant gliomas in vitro. J Neurooncol 39: 237-244, 1998.
14. Kretschmer-Kazemi Far R and Sczakiel G: The activity of siRNA in mammalian cells is related to structural target accessibility: a comparison with antisense oligonucleotides. Nucleic Acids Res 31: 4417-4424, 2003.

15. Elbashir SM, Harborth J, Lendeckel W, Yalcin A, Weber K and Tuschl T: Duplexes of 21-nucleotide RNAs mediate RNA interference in cultured mammalian cells. Nature 411: 494-498, 2001.

16. Kittler R and Buchholz F: RNA interference: gene silencing in the fast lane. Semin Cancer Biol 13: 259-265, 2003.

17. Soutschek J, Akinc A, Bramlage B, Charisse K, Constien R, Donoghue M, Elbashir S, Geick A, Hadwiger P, Harborth J, John M, Kesavan V, Lavine G, Pandey RK, Racie T, Rajeev KG, Rohl I, Toudjarska I, Wang G, Wuschko S, Bumcrot D, Koteliansky V, Limmer S, Manoharan M and Vornlocher HP: Therapeutic silencing of an endogenous gene by systemic administration of modified siRNAs. Nature 432: 173-178, 2004.

18. Harborth J, Elbashir SM, Bechert K, Tuschl T and Weber K: Identification of essential genes in cultured mammalian cells using small interfering RNAs. J Cell Sci 114: 4557-4565, 2001.

19. Bernhardt G, Reile H, Birnbock H, Spruss T and Schönenberger H: Standardized kinetic microassay to quantify differential chemosensitivity on the basis of proliferative activity. J Cancer Res Clin Oncol 118: 35-43, 1992.

20. Blindt R, Bosserhoff AK, vom Dahl J, Hanrath P, Schror K, Hohlfeld T and Meyer-Kirchrath J: Activation of IP and EP(3) receptors alters cAMP-dependent cell migration. Eur J Pharmacol 444: 31-37, 2002.

21. Martinez-Lacaci I, De Santis M, Kannan S, Bianco C, Kim N, Wallace-Jones B, Wechselberger C, Ebert AD and Salomon DS: Regulation of heparin-binding EGF-like growth factor expression in Ha-ras transformed human mammary epithelial cells. J Cell Physiol 186: 233-242, 2001.

22. Unlu A and Leake RE: The effect of EGFR-related tyrosine kinase activity inhibition on the growth and invasion mechanisms of prostate carcinoma cell lines. Int J Biol Markers 18: 139-146, 2003.

23. Guerrero J, Santibanez JF, Gonzalez A and Martinez J: EGF receptor transactivation by urokinase receptor stimulus through a mechanism involving Src and matrix metalloproteinases. Exp Cell Res 292: 201-208, 2004.

24. Bhattacharya A, Lakka SS, Mohanam S, Boyd D and Rao JS: Regulation of the urokinase-type plasminogen activator receptor gene in different grades of human glioma cell lines. Clin Cancer Res 7: 267-276, 2001 .

25. Chen P, Xie H, Sekar MC, Gupta K and Wells A: Epidermal growth factor receptor-mediated cell motility: phospholipase C activity is required, but mitogen-activated protein kinase activity is not sufficient for induced cell movement. J Cell Biol 127: 847-857, 1994.

26. Berens ME, Rief MD, Shapiro JR, Haskett D, Giese A, Joy A and Coons SW: Proliferation and motility responses of primary and recurrent gliomas related to changes in epidermal growth factor receptor expression. J Neurooncol 27: 11-22, 1996.

27. Levitzki A and Gazit A: Tyrosine kinase inhibition: an approach to drug development. Science 267: 1782-1788, 1995.

28. Chakravarti A, Chakladar A, Delaney MA, Latham DE and Loeffler JS: The epidermal growth factor receptor pathway mediates resistance to sequential administration of radiation and chemotherapy in primary human glioblastoma cells in a RASdependent manner. Cancer Res 62: 4307-4315, 2002.

29. Lal A, Glazer CA, Martinson HM, Friedman HS, Archer GE, Sampson JH and Riggins GJ: Mutant epidermal growth factor receptor up-regulates molecular effectors of tumor invasion. Cancer Res 62: 3335-3339, 2002.

30. Steinbach JP, Supra P, Huang HJ, Cavenee WK and Weller M: CD95-mediated apoptosis of human glioma cells: modulation by epidermal growth factor receptor activity. Brain Pathol 12: 12-20, 2002.

31. Lipson KE, Pang L, Huber LJ, Chen H, Tsai JM, Hirth P, Gazit A, Levitzki A and McMahon G: Inhibition of platelet-derived growth factor and epidermal growth factor receptor signaling events after treatment of cells with specific synthetic inhibitors of tyrosine kinase phosphorylation. J Pharmacol Exp Ther 285: 844-852, 1998.

32. Cohen MH, Williams GA, Sridhara R, Chen G, McGuinn WD Jr, Morse D, Abraham S, Rahman A, Liang C, Lostritto R, Baird A and Pazdur R: United States Food and Drug Administration Drug Approval summary: Gefitinib (ZD1839; Iressa) tablets. Clin Cancer Res 10: 1212-1218, 2004. 
33. Shankar PP, Wei H, Davee SM and Funk JL: Parathyroid hormone-related protein is expressed by transformed and fetal human astrocytes and inhibits cell proliferation. Brain Res 868: 230-240, 2000

34. Sweeney C, Fambrough D, Huard C, Diamonti AJ, Lander ES, Cantley LC and Carraway KL III: Growth factor-specific signaling pathway stimulation and gene expression mediated by ErbB receptors. J Biol Chem 276: 22685-22698, 2001.

35. Kowanetz K, Husnjak K, Holler D, Kowanetz M, Soubeyran P, Hirsch D, Schmidt MH, Pavelic K, De Camilli P, Randazzo PA and Dikic I: CIN85 associates with multiple effectors controlling intracellular trafficking of EGF receptors. Mol Biol Cell 15: 3155-3166, 2004.

36. Swindle CS, Tran KT, Johnson TD, Banerjee P, Mayes AM, Griffith L and Wells A: Epidermal growth factor (EGF)-like repeats of human tenascin-C as ligands for EGF receptor. J Cell Biol 154: 459-468, 2001.

37. Graham NA and Asthagiri AR: Epidermal growth factor-mediated T-cell factor/lymphoid enhancer factor transcriptional activity is essential but not sufficient for cell cycle progression in nontransformed mammary epithelial cells. J Biol Chem 279: 23517-23524, 2004.

38. Rickman DS, Bobek MP, Misek DE, Kuick R, Blaivas M, Kurnit DM, Taylor J and Hanash SM: Distinctive molecular profiles of high-grade and low-grade gliomas based on oligonucleotide microarray analysis. Cancer Res 61: 6885-6891, 2001.

39. Van den Boom J, Wolter M, Kuick R, Misek DE, Youkilis AS, Wechsler DS, Sommer C, Reifenberger G and Hanash SM: Characterization of gene expression profiles associated with glioma progression using oligonucleotide-based microarray analysis and real-time reverse transcription-polymerase chain reaction. Am J Pathol 163: 1033-1043, 2003.

40. Taira T, Maeda J, Onishi T, Kitaura H, Yoshida S, Kato H, Ikeda M, Tamai K, Iguchi-Ariga SM and Ariga H: AMY-1, a novel $\mathrm{C}-\mathrm{MYC}$ binding protein that stimulates transcription activity of C-MYC. Genes Cells 3: 549-565, 1998.

41. Yue S, Serra HG, Zoghbi HY and Orr HT: The spinocerebellar ataxia type 1 protein, ataxin-1, has RNA-binding activity that is inversely affected by the length of its polyglutamine tract. Hum Mol Genet 10: 25-30, 2001.

42. Pettersson M, Bessonova M, Gu HF, Groop LC and Jonsson JI: Characterization, chromosomal localization, and expression during hematopoietic differentiation of the gene encoding Arl6ip, ADP-ribosylation-like factor-6 interacting protein (ARL6). Genomics 68: 351-354, 2000

43. Egidy G, Eberl LP, Valdenaire O, Irmler M, Majdi R, Diserens AC, Fontana A, Janzer RC, Pinet F and JuilleratJeanneret L: The endothelin system in human glioblastoma. Lab Invest 80: 1681-1689, 2000 .

44. Vacca F, Bagnato A, Catt KJ and Tecce R: Transactivation of the epidermal growth factor receptor in endothelin-1-induced mitogenic signaling in human ovarian carcinoma cells. Cancer Res 60: 5310-5317, 2000.

45. Rajeevan MS, Ranamukhaarachchi DG, Vernon SD and Unger ER: Use of real-time quantitative PCR to validate the results of cDNA array and differential display PCR technologies. Methods 25: 443-451, 2001

46. Eller JL, Longo SL, Hicklin DJ and Canute GW: Activity of anti-epidermal growth factor receptor monoclonal antibody $\mathrm{C} 225$ against glioblastoma multiforme. Neurosurgery 51: 1005-1014, 2002 .
47. Halatsch ME, Gehrke EE, Vougioukas VI, Botefur IC, ABorhani F, Efferth T, Gebhart E, Domhof S, Schmidt U and Buchfelder M: Inverse correlation of epidermal growth factor receptor messenger RNA induction and suppression of anchorage-independent growth by OSI-774, an epidermal growth factor receptor tyrosine kinase inhibitor, in glioblastoma multiforme cell lines. J Neurosurg 100: 523-533, 2004.

48. Stea B, Falsey R, Kislin K, Patel J, Glanzberg H, Carey S, Ambrad AA, Meuillet EJ and Martinez JD: Time and dosedependent radiosensitization of the glioblastoma multiforme U251 cells by the EGF receptor tyrosine kinase inhibitor ZD1839 ('Iressa'). Cancer Lett 202: 43-51, 2003.

49. Sundberg AL, Almqvist Y, Tolmachev V and Carlsson J: Treatment of cultured glioma cells with the EGFR-TKI gefitinib ('Iressa', ZD1839) increases the uptake of astatinated EGF despite the absence of gefitinib-mediated growth inhibition. Eur J Nucl Med Mol Imaging 30: 727-729, 2003.

50. Rich JN, Reardon DA, Peery T, Dowell JM, Quinn JA, Penne KL, Wikstrand CJ, van Duyn LB, Dancey JE, McLendon RE, Kao JC, Stenzel TT, Ahmed Rasheed BK, Tourt-Uhlig SE, Herndon JE II, Vredenburgh JJ, Sampson JH, Friedman AH, Bigner DD and Friedman HS: Phase II trial of gefitinib in recurrent glioblastoma. J Clin Oncol 22: 133-142, 2004.

51. Li B, Chang CM, Yuan M, McKenna WG and Shu HK: Resistance to small molecule inhibitors of epidermal growth factor receptor in malignant gliomas. Cancer Res 63: 7443-7450, 2003.

52. Lammering G, Hewit TH, Valerie K, Lin PS, Contessa JN and Schmidt-Ullrich RK: Anti-erbB receptor strategy as a gene therapeutic intervention to improve radiotherapy in malignant human tumours. Int J Radiat Biol 79: 561-568, 2003.

53. Nagy P, Arndt-Jovin DJ and Jovin TM: Small interfering RNAs suppress the expression of endogenous and GFP-fused epidermal growth factor receptor (erbB1) and induce apoptosis in erbB1overexpressing cells. Exp Cell Res 285: 39-49, 2003.

54. Zhang M, Zhang X, Bai CX, Chen J and Wei MQ: Inhibition of epidermal growth factor receptor expression by RNA interference in A549 cells. Acta Pharmacol Sin 25: 61-67, 2004

55. Dancey J: Epidermal growth factor receptor inhibitors in clinical development. Int J Radiat Oncol Biol Phys 58: 1003-1007, 2004.

56. Lynch TJ, Bell DW, Sordella R, Gurubhagavatula S, Okimoto RA, Brannigan BW, Harris PL, Haserlat SM, Supko JG, Haluska FG, Louis DN, Christiani DC, Settleman J and Haber DA: Activating mutations in the epidermal growth factor receptor underlying responsiveness of non-small-cell lung cancer to gefitinib. N Engl J Med 350: 2129-2139, 2004

57. Paez JG, Janne PA, Lee JC, Tracy S, Greulich H, Gabriel S, Herman P, Kaye FJ, Lindeman N, Boggon TJ, Naoki K, Sasaki H, Fujii Y, Eck MJ, Sellers WR, Johnson BE and Meyerson M: EGFR mutations in lung cancer: correlation with clinical response to gefitinib therapy. Science 304: 1497-1500, 2004.

58. A Chakravarti A, Seiferheld W, Tu X, Wang H, Chang H, Ang K, Hammond E, Curran W, Mehta M Jr: Immunohistochemically determined total epidermal growth factor receptor levels not of prognostic value in newly diagnosed glioblastoma multiforme. Int J Radiat Oncol Biol Phys 62: 318-327, 2005. 